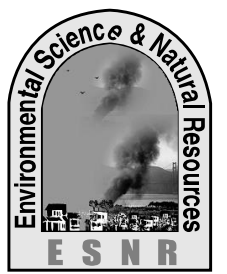

\title{
Adulteration of Raw Milk in Selected Regions of Tangail District of Bangladesh
}

\author{
L. Bari, M. R. Hoque*, M. S. A. Reza, M. A. Hossain and A. Islam
}

Department of Food Technology and Nutritional Science

Mawlana Bhashani Science and Technology University, Santosh, Tangail-1902

* Corresponding author: h.riadul09@gmail.com

\begin{abstract}
At the present time adulteration of food especially raw milk is becoming a burning issue. Normally milk is adulterated with water, starch, skim milk powder, sugar, detergent, and fat, recently formalin also added with milk to increase the shelf life of milk. Thatôs why it is very essential to detect the prevalence of adulteration of milk. The present experiment was conducted to know the adulteration of milk. Total thirty milk samples were collected from five different bazaars (Tangail town, Santosh Bazaar, Porabari Bazaar, Boilla Bazaar, Bajitpur Bazaar) of Tangail district where six samples were taken from each entry point. The mean Specific gravity was $1.021,1.020,1.019,1.019$ and 1.020 respectively which were lower than standard 1.032 (BSTI, 2000). The results clearly suggest that water was the most common adulterant in almost all sample of raw milk collected. $56.67 \%$ and $50 \%$ samples were adulterated with starch and skim milk powder respectively. Two types of preservatives namely borax and sodium bicarbonate were detected in the fluid milk from the study areas. Out of all samples, $23.33 \%$ was adulterated with sodium bicarbonate and $16.66 \%$ with borax. However, none of the samples contained either formalin or hydrogen peroxide. It could therefore be inferred that, the consumers need to be more cautious regarding the quality of raw milk.
\end{abstract}

Key words: Adulteration, Raw milk, Starch, Skim milk powder, water

\section{Introduction}

Milk has been recognized as an almost complete food, it supplies nutrients like good quality proteins, fat, carbohydrates, vitamins and minerals in significant amount than any other single food (Neumann et al. 2002). Milk is the lacteal secretion, practically free from colostrums, obtained by the complete milking of healthy cows, five days after and 15 days before parturition, which contains not less than 8.5 percent milk solids-not-fat and not less than 3.5 percent milk fat (U.S. Public Health Service, 1965 and Itzerott, 1960). Although milk contains all the nutrients adequately but now a dayôs milk is adulterated in a wide varieties of way. Producer adopt this way by considering the profit and to meet the gap between demand and production. Adulteration is an act of intentionally debasing the quality of food offered for sale either by admixture or substitution of inferior substances or by the removal of some valuable ingredients (FDA, 1995). However, Adulteration of milk is usually done by adding inferior cheaper materials or elements like pond water, cane sugar and powdered milk (Prasad, 1999). A study conducted by Chanda et al. (2012) in Barishal district of Bangladesh founded that all of the milk samples were adulterated with water irrespective of collection points and months. Cane sugar, powdered milk, starch, formalin and sodium bicarbonate were also detected. Haasnoot et al. (2004) showed that milk adulteration, poor hygiene, malpractices, lack of preservation technology, cooling facilities and sanitation conditions are the main cause of losses in quantity and poor quality of milk. This adulterated milk may cause various diseases to the consumers. Water decreases the nutritive value of milk which if contaminated poses a health risk especially to infants and children. Starch can cause diarrhea due to the effects of undigested starch in colon and may prove very fatal for diabetic patients. Detergents cause gastroï intestinal complications (Singuluri and Sukumaran, 2014). Octylphenol and nonylphenol parts of detergents cause breast cancer (Ali et al. 2005). Formalin causes vomiting, diarrhea and abdominal pain. Larger doses may cause decreased body temp, shallow respiration, and weak irregular pulse and unconscious (Gwin et al. 2009). By considering the harmful effect of adulteration, this study was conducted to detect the adulteration of milk in the Tangail sadar upazilla of Tangail district.

\section{Materials and Methods}

\section{Study area}

A cross sectional study was carried out among the five different bazar (Tangail town, Santosh Bazaar, Porabari Bazaar, Boilla Bazaar, Bajitpur Bazaar) of Tangail Sadar upazilla. It took six months (April to September 2014) to carry out the experiment, under the department of Food Technology and Nutritional Science, MBSTU.

\section{Collection of samples}

A total 30 sample each sample contain $250 \mathrm{ml}$ were collected by sterilized bottle. The samples were immediately cooled in a cool box containing Ice Packs. The milk was analyzed in the laboratory within 2 hours from arrival.

\section{Adulteration detection methods Preparation of sample}

The sample was prepared according to the DGHS (2005). The sample was warm to $37^{\circ} \mathrm{Ci} 40^{\circ} \mathrm{C}$ then it was transferred to the beaker and allows the 
sample to come to room temperature $\left(26^{\circ} \mathrm{C}-28^{\circ} \mathrm{C}\right)$ and withdraw immediately for analysis.

\section{Detection of starch in milk}

After preparation of the sample about $5 \mathrm{ml}$ of milk was taken in a test tube. Then 1-2 drops of iodine solution was added to the test tube. Development of blue/blue black color indicates presence of starch which disappears when sample is boiled and reappears on cooling.

Detection of skimmed milk powder in natural milk After preparation of the sample about $5 \mathrm{ml}$ of milk was taken in a test tube. It was then stirred properly. Nitric acid was then added drop by drop with a dropper. Development of orange color, it indicates the milk is adulterated with skim milk powder. Samples without skim milk powder show yellow color.

\section{Detection of water}

Adulteration of milk with water was checked by lactometer reading. The raw milk was poured into a (100 ml) measuring cylinder and a lactometer was dropped in the milk to slowly sink down. Further, the lactometer reading was taken and recorded in Lactometer degree $\left({ }^{\circ} \mathrm{L}\right)$. The temperature during measuring was approximately $20-22^{\circ} \mathrm{C}$. If the reading is below the standard then it was considered to be adulterated with water.

\section{Determination of specific gravity}

The specific gravity was measured by using the following formula using lactometer reading: Milk density $=1+\left(\right.$ lactometer reading $\left.1000^{-1}\right)$

\section{Detection of formalin}

Formalin detection was done by formalin detection KIT developed by Institution of Food Science and Technology (BCSIR).
Detection of sodium bicarbonate, hydrogen peroxide and borax

The type of preservatives added to the fluid milk was detected by using chemical tests. All tests were conducted as per DGHS (2005).

\section{Results and Discussion}

The adulterants of raw milk collected from these five different places are presented in Table 1. It shows that among five different Bazaar except two sample of Tangail Town lactometer reading is lower than standard $\left(28^{\circ} \mathrm{L}\right.$ to $\left.32^{\circ} \mathrm{L}\right)$ (BSTI, 2000) which is almost similar to the findings of Chanda et al. (2012) it was observed that all samples collected from five different entry points were adulterated with water throughout the whole study period. This is due to the availability of water and to increase the volume and also to neutralize the developed acidity of fluid milk for prolonged shelf life.

Starch was detected as adulterant by $66.67 \%$ of the milk samples collected from Tangail Town and Santosh Bazar, 50\% sample was adulterated with starch in Porabari bazaar and Bajitpur Bazar. The results of starch detection totally disagreed with the results of Islam et al. (2013) who found that no milk was adulterated with starch. Skim milk powder was detected by $50.002 \%$ of all samples. However, maximum $66.67 \%$ of the milk samples collected from Porabari and Bajitpur was found to be adulterated with powdered milk. Interestingly, samples collected from Boilla bazaar shows $16.67 \%$ adulterated with skim milk powder. But all of the samples were totally free from adulterated with cane sugar.

Table 1. Presence of adulterant (\% positive sample) in the raw milk collected from different points of Tangail district $(\mathrm{N}=30)$

\begin{tabular}{|c|c|c|c|c|c|c|c|}
\hline Adulterant & $\begin{array}{c}\text { Tangail } \\
\text { Town }\end{array}$ & $\begin{array}{c}\text { Santosh } \\
\text { Bazar }\end{array}$ & $\begin{array}{c}\text { Porabari } \\
\text { Bazar }\end{array}$ & $\begin{array}{c}\text { Boilla } \\
\text { Bazar }\end{array}$ & $\begin{array}{c}\text { Bajitpur } \\
\text { Bazar }\end{array}$ & Average & $\begin{array}{c}\text { Sig. } \\
\text { level }\end{array}$ \\
\hline Water & 66.67 & 100.00 & 100.00 & 100.00 & 100.00 & 93.33 & $*$ \\
\hline Starch & 66.67 & 66.67 & 50.00 & 33.33 & 50.00 & 53.33 & $*$ \\
\hline $\begin{array}{c}\text { Skim milk } \\
\text { powder }\end{array}$ & 50.00 & 50.00 & 66.67 & 16.67 & 66.67 & 50.00 & $*$ \\
\hline Cane sugar & 0.00 & 0.00 & 0.00 & 0.00 & 0.00 & 0.00 & NS \\
\hline
\end{tabular}

$N S$, non-significant ( $p>0.05) ;{ }^{*}, p<0.05$

The specific gravity of milk was ranged from 1.015 to 1.029 as presented in Table 2. The results of specific gravity indicates that milk collected from five bazaar except two sample of Tangail town was adulterated with water it was similar to Lateef et al.
(2009) he observed that the specific gravity of cow's milk was $(1.02 \pm 0.010)$. But the range of specific gravity of milk sample collected from Sombhuganj bazaar was 1.027 to 1.032 . 
Table 2. Specific gravity of milk samples collected from 5 local markets of Tangail

\begin{tabular}{|c|c|c|c|c|c|}
\hline Sample no & Tangail town & $\begin{array}{c}\text { Santosh } \\
\text { Bazaar }\end{array}$ & $\begin{array}{c}\text { Porabari } \\
\text { Bazaar }\end{array}$ & Boilla Bazaar & Bajitpur Bazaar \\
\hline Sample ï 1 & 1.019 & 1.019 & 1.015 & 1.020 & 1.018 \\
\hline Sample Ï 2 & 1.018 & 1.022 & 1.017 & 1.015 & 1.019 \\
\hline Sample ï 3 & 1.018 & 1.020 & 1.019 & 1.013 & 1.019 \\
\hline Sample ï 4 & 1.019 & 1.010 & 1.023 & 1.019 & 1.020 \\
\hline Sample - 5 & 1.029 & 1.014 & 1.020 & 1.018 & 1.021 \\
\hline Sample ï 6 & 1.028 & 1.022 & 1.022 & 1.015 & 1.021 \\
\hline
\end{tabular}

Table 3. Presence of preservatives ( $\%$ positive sample) in the raw milk collected from different points of Tangail district $(\mathrm{N}=30)$

\begin{tabular}{|l|c|c|c|c|c|c|c|}
\hline \multicolumn{1}{|c|}{ Preservatives } & $\begin{array}{c}\text { Tangail } \\
\text { Town }\end{array}$ & $\begin{array}{c}\text { Santosh } \\
\text { Bazar }\end{array}$ & $\begin{array}{c}\text { Porabari } \\
\text { Bazar }\end{array}$ & $\begin{array}{c}\text { Boilla } \\
\text { Bazar }\end{array}$ & $\begin{array}{c}\text { Bajitpur } \\
\text { Bazar }\end{array}$ & Average & $\begin{array}{c}\text { Sig. } \\
\text { level }\end{array}$ \\
\hline Sodium bicarbonate & 33.33 & 16.67 & 33.33 & 0.00 & 33.33 & 23.33 & $*$ \\
\hline Hydrogen peroxide & 0.00 & 0.00 & 0.00 & 0.00 & 0.00 & 0.00 & NS \\
\hline Borax & 33.33 & 16.67 & 16.67 & 0.00 & 16.67 & 16.66 & $*$ \\
\hline Formalin & 0.00 & 0.00 & 0.00 & 0.00 & 0.00 & 0.00 & NS \\
\hline
\end{tabular}

$N S$, non-significant ( $p>0.05) ; *, p<0.05$

In raw milk, chemicals are added to increase the shelf life. In this study, milk samples were tested for detecting borax, hydrogen per oxide, sodium bicarbonate and formalin. On average, $23.33 \%$ of the milk samples were detected as sodium bicarbonate positive (Table 3 ) and $16.66 \%$ of the milk samples were detected as borax positive. Hydrogen peroxide and formalin were not detected in any sample of the study area. This result is a bit different from the findings of Debnath et al. (2009) and Das et al. (2010) who found only formalin as added preservative in raw milk in Chittagong metro-politan area.

\section{References}

Ali, N.; John, A. and Rehman, F. 2005. Corpse preservatives being used in unpacked milk. Daily Times, $4^{\text {th }}$ Dec.

BSTI (Bangladesh Standard and Testing Institution). 2000. BS specification for raw milk, Dhaka.

Chanda, T. Debnath, G. K. Hossain, M. E. Islam, M. A. and Begum, M. K. 2012. Adulteration of raw milk in the rural areas of Barisal district of Bangladesh. Bang. J. Anim. Sci. 41 (2): 112115.

Das, S.; Debnath, G. K.; Chanda, T.; Alim, M. A. and Sarker, S. 2010. A study on quality of milk from farm to shop in Chittagong Metropolitan area. Int. J. Anim. Fish. Sci. 3: 252-256.

Debnath, G. K. Kober, A. K. M. and Chanda, G. C. 2008. Quality of fluid milk available in Chittagong Metropolitan area. In: Debnath, N.C. Khan, K. I. Hossain, M. E. Barua, H. Alam, R. Ahmed, S. S. U. and Hossain, S. (eds.). Proc. 6 ${ }^{\text {th }}$ P. 1-18. Sci. Con. 4-6 March, Khulshi, Chittagong, Bangladesh. pp. 178-182.

\section{Conclusions}

It is apparent from the analyses that a large number of samples procured did not conform to the legal standards. From the individual sample study we can conclude that the rate of adulteration is relatively low in Boilla bazaar than others place. If we want to say about the type of adulteration it may be only adding water, starch and skim milk powder. The results clearly suggest that water was the most common adulterant in almost all sample of raw milk collected. We found $56.67 \%$ samples were adulterated with starch and $50 \%$ samples were adulterated with skim milk powder. We found very few sample adulterated with sodium bi-carbonate and borax but we did not found any sample adulterated with formalin and hydrogen peroxide.

DGHS (Directorate General of Health Service). 2005.. Manual of methods of analysis of foods (milk and milk products). Ministry of health and family welfare, India.

Gwin, M. C. Lienert, C. V. and Kennedy, J. 2009. Formaldehyde exposure and asthma in children. A systematic review, Environ. Health Perspect. 118: 313-317.

Haasnoot, W. Smits, N. G. E. Kemmers-Voncken, A. E. M. and Bremer, M. G. E. 2004. Fast biosensor immunoassays in milk of ewes and goats. J. of Dairy Sci. 71:322-329.

Islam, M. A.; Rashid, M. H.; Kajal, M. F. I.; and Alam, M. S. 2013. Quality of milk available at local markets of Muktagacha upazila in Mymensingh district. J. Bangladesh Agril. Univ. 11(1): 119ї 124.

Itzerott, G. 1960. Notes on milk and indigenous dairy products of Pakistan. Dairy Science Abstrs. 22: 7-11. 
Lateef, M. A.; Faraz, M. I.; Mustafa, P.; Akthar ans Bashir, M. K. 2009. Detection of adulterants and chemical composition of milk supplied to canteens of various hospitals in Faisalabad city. Pak. J. Zool. 9: 139-142.

Neumann, C. G.; Harris, D. M. and Rogers, L. M. 2002. Contribution of animal source foods in improving diet quality and function in children in the developing world. Nutr. Res.22: 193220.

Prasad, J.; Tyagi, A. K. and Neeraj. 1999. Principles and Practices of Animal Nutrition. $1^{\text {st }}$ edn. Kalyani Publishers. New Delhi-110002.
Singuluri and Sukumaran. 2014. Milk Adulteration in Hyderabad, India Ï A Comparative Study on the Levels of Different Adulterants Present in Milk. J Chromatograph Separat Techniq. 5:1.

U.S. Public Health Services. 1965. Grade A Pasteurise milk ordinance, U.S. Department of Public Health Education and Welfare Service. P.I. 